Cytologia focus:

\title{
Which Is a Reliable Approach in the Generation of Artificial Minichromosomes, Bottom-Up or Top-Down?
}

\author{
Satoru Fujimoto and Sachihiro Matsunaga* \\ Department of Applied Biological Science, Faculty of Science and Technology, Tokyo University of Science, \\ 2641 Yamazaki, Noda, Chiba 278-8510, Japan \\ Received July 26, 2016; accepted August 8, 2016
}

\begin{abstract}
Summary Artificial minichromosomes are exciting transgenic tools because they replicate and segregate autonomously and are not integrated into the host genome. They enable efficient delivery of an extremely large gene or multiple genes with high stability. There are two approaches to construct artificial minichromosomes: bottom-up and top-down. The construction of artificial minichromosomes addresses the basic questions of the structure and function of chromosomes. Advances in DNA synthesis technology will open a new era of generating artificial minichromosomes.
\end{abstract}

Key words Chromosome structure, Minichromosome, Artificial chromosome, Centromere, Telomere, Synthetic chromosome, DNA synthesis.

Cytogenetical and karyotypic studies have revealed variations of chromosomes in size, morphology, and number in various clades of plant and animal species (Al-Dakan and Al-Saleh 2015, Al-Qahtani et al. 2014, Arslan and Zima 2014, Bagane et al. 2014, Çakmak and Koca 2014, Deshpande et al. 2014, El-Esawi and Sammour 2014, Gholave et al. 2014, Haroun and Alotaibi 2015, Jantarat et al. 2014a, 2014b, Jumrusthanasan et al. 2015, Kaewmad et al. 2014, Kaewsri et al. 2014a, 2014b, 2014c, Kantek et al. 2015, Kasiroek et al. 2014, Kaur and Singhal 2015, Khakhong et al. 2014, Kumar et al. 2015, Kumar et al. 2014, Li et al. 2015, Maneechot et al. 2015, Martin et al. 2015, Miura and Iwatsubo 2014, Parai and Mukherjee 2014, Park 2015, Patawang et al. 2014a, 2014b, 2015, Phimphan et al. 2015, Pierozzi and Baroni 2014, Pinthong et al. 2014, 2015, Qumsiyeh et al. 2014, Rezaei et al. 2014, Samanta et al. 2015, Sato et al. 2015, Supanuam et al. 2015, Supiwong et al. 2015, Tahami et al. 2014, Tanomtong et al. 2014a, 2014b, 2015, Venkatesh and Munirajappa 2015, Venkatesh et al. 2014, Walia et al. 2015). Cytogenetical techniques including banding methods and FISH have revealed the evolutionary process in structural and number changes of chromosomes (Lombello and Pinto-maglio 2014, Mahbub et al. 2014, Manzum et al. 2014, Tungkajiwangkoon et al. 2015, Bansal and Kaur 2015, Akter et al. 2015, Hizume 2015, Hizume and Kan 2015, Imran et al. 2015, Kantek et al. 2015, Shibata and Hizume 2015, Matsunaga 2016). The chromosome evolutionary pro-

*Corresponding author, e-mail: sachi@rs.tus.ac.jp DOI: $10.1508 /$ cytologia.81.251 cess or the effect of chromosomal changes is speculative, and it is difficult to reproduce the process and mechanism. However, construction of artificial chromosomes can supply an answer to the basic question of how chromosomal structure forms (Nakano et al. 2008).

An artificial minichromosome can act as a new endogenous chromosome in the host cells. The artificial chromosomes are capable of replicating and segregating autonomously. Artificial chromosomes can be used for delivering an extremely large genetic region or multiple genes to host cells without integration into the host genome, thus preventing the position effect of introduced genes, insertional mutagenesis and genome instability (Costantini et al. 1989, al-Shawi et al. 1990, Reuter and Spierer 1992, Dobie et al. 1996, Yin et al. 2004, O'Connor and Crystal 2006). There are two strategies for producing artificial chromosomes (Hadlaczky 2011, Gaeta and Krishnaswamy 2011) (Fig. 1). The first one involves the de novo assembly of artificial chromosomes with artificial compositions of cloned chromosomal components delivered into cells (bottom-up approach). The second one involves truncation of endogenous chromosomes to create small chromosomes (top-down approach).

The bottom-up approach was first established in yeast (Murray and Szostak 1983). The primary components of a yeast artificial chromosome are the autonomously replicating sequence, a centromere, and telomeres from the yeast. Vectors larger than $55 \mathrm{~kb}$ with the three components became relatively stable through mitosis and meiosis (Murray and Szostak 1983). In mammalian cells, the bottom-up approach to generate mamma- 
(a) Bottom-up approach

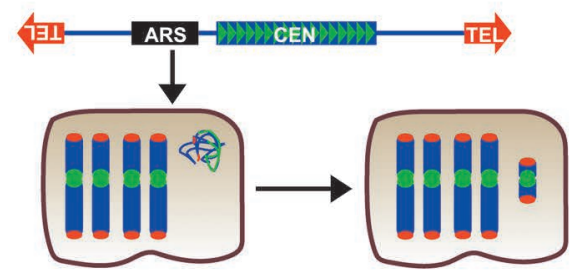

de novo assembly of cloned DNA componen (b) Top-down approach

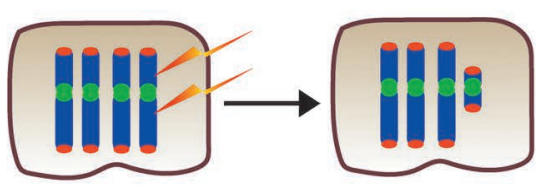

Chromosome truncation

Fig. 1. Generation strategy of artificial minichromosomes: bottom-up approach versus top-down approach. ARS: autonomously replicating sequence, CEN: centromere sequence, TEL: telomere sequence.

lian artificial chromosomes (MACs) was successfully adapted by using synthetic arrays of centromeric alpha satellite DNA with telomeric DNA in human HT1080 cells (Harrington et al. 1997, Ikeno et al. 1998). The resulting linear microchromosomes, containing foreign alpha satellite DNA, were mitotically stable and bound centromere proteins. Moreover, telomeric sequences were not essential for de novo chromosome formation as a circular MAC from the alpha satellite DNA (Ebersole et al. 2000). However, during the delivery to the cells, the DNA was subjected to multimierization resulting in artificial chromosomes which are much larger than the original constructs used for the transformation. Moreover, reproducible generation of MACs has only been achieved in the HT1080 cell line (Irvine et al. 2005). In plant cells, the bottom-up approach was also attempted. Only maize cells with bottom-up artificial chromosomes were reported using centromeric sequences (Carlson et al. 2007, Ananiev et al. 2009). After biolistic bombardment of maize centromeric sequences into embryonic maize tissue and subsequent transgene selection, microscopic analysis revealed some small fragments with centromeric signals independent of the host maize chromosomes. These fragments were reported to be transmitted during mitosis and meiosis. However, information about whether the fragments have centromere proteins or not is lacking (Carlson et al. 2007), and the effect of telomere mediated chromosome truncation cannot be denied (Ananiev et al. 2009). So, de novo assembly of autonomous maize minichromosomes remains a matter of debate (Houben et al. 2008, Birchler et al. 2010).

Although the bottom-up approach has been successful in budding yeast and human HT1080 cells, many cells often only exhibited inserted centromeric sequences without centromeric activity (Baum et al. 2006, Phan et al. 2007). An idea arises that the epigenetic state of the centoromere may be important rather than the primary DNA sequence (Karpen and Allshire 1997). One attempt is made using Drosophila melanogaster. It has been described with the $\mathrm{lacO} / \mathrm{LacI}$ system (Hirakawa and Matsunaga 2016), which is based on the artificial targeting of the LacI-tagged CENP-A of Drosophila (CID) to transgenic tandem repeat arrays of the $l a c O$ sequences (Mendiburo et al. 2011). Surprisingly, the tethering of the fusion protein CID-GFP-LacI alone is sufficient not only for the ectopic centromere formation, but also for the establishment of extrachromosomal lacO minichromosomes, which are mitotically stable for several cell generations, even after eliminating CID-GFP-LacI (Mendiburo et al. 2011). To establish an epigenetically stable state for the CENP-A assembly, the tetO/tetR system was used (Ohzeki et al. 2012). The tetO/tetR system is based on the artificial targeting of the tetR-tagged histone modification enzyme to tet $O$ sites within the synthetic alpha satellite DNA arrays. The exogenous histone acetyltransferase activity is required for the kinetochore assembly on the extrachromosomal tetO containing array. The kinetochores no longer require this exogenous activity to maintain their structure and function (Ohzeki et al. 2012).

The top-down approach is accomplished by truncating the natural chromosome by several different routes. In fission yeast, minichromosome $\mathrm{Ch}^{16}$ and its derivatives were created by $\gamma$-irradiation (Niwa et al. 1986). The minichromosomes were derived from the pericentrometic region of chromosome III and from 120 to $750 \mathrm{~kb}$ in length (Niwa et al. 1989). To generate such a kind of truncated minichromosomes, the double strand breakages should occur at multiple sites (e.g., near centromere and telomere), so the efficiency is quite low. Introduction of cloned telomeric repeats into mammalian cultured cells cause chromosome breakages by formation of new telomere at the integration site (Farr et al. 1991). This technique was further refined for generation of MACs (Farr et al. 1992, Itzhaki et al. 1992) including using homologous recombination-proficient chicken DT40 cells via microcell-mediated chromosome transfer (Kuroiwa et al. 1998). The telomere mediated approach was also used for generation of truncated chromosomes in various organism including Candida albicans (Kabir and Rustchenko 2005) and Xenopus (Wuebbles and Jones 2007). In plants, maize (Yu et al. 2006), Arabidopsis thaliana (Nelson et al. 2011, Teo et al. 2011), barley (Kapusi et al. 2012), and rice (Xu et al. 2012) were reported. However, for the minichromosome generation in plants, further breakthroughs like DT40 cell mediated truncation in mammalian cells are required because of the inefficiency of target integration of telomeric sequence. 
A ring minichromosome was artificially generated by using the DNA sequence specific recombination system, Cre/LoxP combination with DNA transposon system, and activator $(A c) /$ dissociation $(D s)$ in $A$. thaliana $(\mathrm{Mu}-$ rata et al. 2013). T-DNA was inserted into the centromere of chromosome 2 that contained two LoxP sites for Cre-mediated recombination. One of the $\operatorname{Lox} P$ sites was transposition by the $A c / D s$ system to two LoxP sites containing centromeric region. Expression of the Cre recombinase excises the region between these LoxP sites, resulting in the formation of a ring minichromosome (Murata et al. 2013). In mammalian cells, $2.4 \mathrm{Mb}$ of the gene can be successfully integrated into the MACs via Cre/LoxP site specific recombination system (Katoh et al. 2004, Ayabe et al. 2005, Hoshiya et al. 2009), and this system can be applied not only to cultured cells but also to mice (Kazuki et al. 2008). In plants, targeted transgene integration into minichromosomes also was achieved by using the Cre/LoxP system (Yu et al. 2007).

Advances in DNA synthesis technology may put an end to the conflict in the two approaches of the construction of artificial minichromsomes. Recently, a $273 \mathrm{~kb}$-chromosome of Saccharomyces cerevisiae was completely synthesized (Annaluru et al. 2014). It is functional although its DNA sequence excludes subtelomeric regions, introns, tRNAs and transposons from native chromosome III. This success indicates that artificial minichromsomes were freely designed using the bottom-up approach to at least the $\sim 1 \mathrm{Mbp}$ level. In the near future, various types of artificial minichromosomes with desired functions and DNA sequences for animal and plant cells will be constructed using DNA synthesis technology.

\section{Acknowledgements}

This work was supported by CREST Grants from the Japan Science and Technology Agency to S. M. and MEXT/JSPS KAKENHI (JP25120726, JP26291067 and JP15H05962) to S. M.

\section{References}

Akter, L., Mahbub, M., Habib, M. A. and Alam, S. S. 2015. Characterization of three varieties of Lathyrus sativus $\mathrm{L}$. by fluorescent karyotype and RAPD analysis. Cytologia 80: 457-465.

Al-Dakan, S. A. and Al-Saleh, A. A. 2015. Karyotype determination of rock hyrax Procavia capensis in Saudi Arabia. Cytologia 80: 287-293.

Al-Qahtani, A. H., Al-Khalifa, M. S. and Al-Saleh, A. A. 2014. Karyotype, meiosis and sperm formation in the red palm weevil Rhynchophorus ferrugineus. Cytologia 79: 235-242.

al-Shawi, R., Kinnaird, J., Burke, J. and Bishop, J. O. 1990. Expression of a foreign gene in a line of transgenic mice is modulated by a chromosomal position effect. Mol. Cell. Biol. 10: 1192 1198.

Ananiev, E. V., Wu, C., Chamberlin, M. A., Svitashev, S., Schwartz, C., Gordon-Kamm, W. and Tingey, S. 2009. Artificial chromo- some formation in maize (Zea mays L.). Chromosoma 118 $157-177$.

Annaluru, N., Muller, H., Mitchell, L. A., Ramalingam, S., Stracquadanio, G., Richardson, S. M., Dymond, J. S., Kuang, Z., Scheifele, L. Z., Cooper, E. M., Cai, Y., Zeller, K., Agmon, N., Han, J. S., Hadjithomas, M., Tullman, J., Caravelli, K., Cirelli, K., Guo, Z., London, V., Yeluru, A., Murugan, S., Kandavelou, K., Agier, N., Fischer, G., Yang, K., Martin, J. A., Bilgel, M., Bohutski, P., Boulier, K. M., Capaldo, B. J., Chang, J., Charoen, K., Choi, W. J., Deng, P., DiCarlo, J. E., Doong, J., Dunn, J., Feinberg, J. I., Fernandez, C., Floria, C. E., Gladowski, D., Hadidi, P., Ishizuka, I., Jabbari, J., Lau, C. Y., Lee, P. A., Li, S., Lin, D., Linder, M. E., Ling, J., Liu, J., Liu, J., London, M., Ma, H., Mao, J., McDade, J. E., McMillan, A., Moore, A. M., Oh, W. C., Ouyang, Y., Patel, R., Paul, M., Paulsen, L. C., Qiu, J., Rhee, A., Rubashkin, M. G., Soh, I. Y., Sotuyo, N. E., Srinivas, V., Suarez, A., Wong, A., Wong, R., Xie, W. R., Xu, Y., Yu, A. T., Koszul, R., Bader, J. S., Boeke, J. D. and Chandrasegaran, S. 2014. Total synthesis of a functional designer eukaryotic chromosome. Science 344: 55-58.

Arslan, A. and Zima, J. 2014. The C-Banding and Ag-NOR distribution patterns in the fallow deer Dama dama (Mammalia: Cervidae) from Turkey. Cytologia 79: 181-185.

Ayabe, F., Katoh, M., Inoue, T., Kouprina, N., Larionov, V. and Oshimura, M. 2005. A novel expression system for genomic DNA loci using a human artificial chromosome vector with transformation-associated recombination cloning. J. Hum. Genet. 50: 592-599.

Bagane, S. A., Kattee, A. V., Sardesai, M. M., Lekhak, M. M. and Yadav, S. R. 2014. Mitotic chromosome studies in Nesphostylis bracteata, an endemic legume from Western Ghats. Cytologia 79: $59-62$.

Bansal, N. and Kaur, H. 2015. C-heterochromatin distribution and its base composition in four species of Mictini (Heteroptera, Coreidae, Coreinae). Cytologia 80: 405-413.

Baum, M., Sanyal, K., Mishra, P. K., Thaler, N. and Carbon, J. 2006. Formation of functional centromeric chromatin is specified epigenetically in Candida albicans. Proc. Natl. Acad. Sci. U.S.A. 103: $14877-14882$.

Birchler, J. A., Krishnaswamy, L., Gaeta, R. T., Masonbrink, R. E. and Zhao, C. 2010. Engineered minichromosomes in plants. CRC Crit. Rev. Plant Sci. 29: 135-147.

Çakmak, F. and Koca, S. 2014. Chorthippus (Glyptobothrus) bornhalmi Harz, 1971 karyotype analysis. Cytologia 79: 509-516.

Carlson, S. R., Rudgers, G. W., Zieler, H., Mach, J. M., Luo, S., Grunden, E., Krol, C., Copenhaver, G. P. and Preuss, D. 2007. Meiotic transmission of an in vitro-assembled autonomous maize minichromosome. PLoS Genet. 3: 1965-1974.

Costantini, F., Radice, G., Lee, J. L., Chada, K. K., Perry, W. and Son, H. J. 1989. Insertional mutations in transgenic mice. Prog. Nucleic Acid Res. Mol. Biol. 36: 159-169.

Deshpande, S. M., Gosavi, K. V. C. and Yadav, S. R. 2014. Karyomorphological work in two endemic species of Tricholepis (Asteraceae) in India. Cytologia 79: 561-566.

Dobie, K. W., Lee, M., Fantes, J. A., Graham, E., Clark, A. J., Springbett, A., Lathe, R. and McClenaghan, M. 1996. Variegated transgene expression in mouse mammary gland is determined by the transgene integration locus. Proc. Natl. Acad. Sci. U.S.A. 93: 6659-6664.

Ebersole, T. A., Ross, A., Clark, E., McGill, N., Schindelhauer, D., Cooke, H. and Grimes, B. 2000. Mammalian artificial chromosome formation from circular alphoid input DNA does not require telomere repeats. Hum. Mol. Genet. 9: 1623-1631.

El-Esawi, M. A. and Sammour, R. 2014. Karyological and phylogenetic studies in the genus Lactuca L. (Asteraceae). Cytologia 79: 269-275. 
Farr, C., Fantes, J., Goodfellow, P. and Cooke, H. 1991. Functional reintroduction of human telomeres into mammalian cells. Proc. Natl. Acad. Sci. U.S.A. 88: 7006-7010.

Farr, C. J., Stevanovic, M., Thomson, E. J., Goodfellow, P. N. and Cooke, H. J. 1992. Telomere-associated chromosome fragmentation: Applications in genome manipulation and analysis. Nat. Genet. 2: 275-282.

Gaeta, R. T. and Krishnaswamy, L. 2011. Engineered plant minichromosomes. Methods Mol. Biol. 701: 131-146.

Gholave, A. R., Jadhav, J. P. and Yadav, S. R. 2014. Cytotaxonomical studies on three varieties of Amorphophallus commutatus (Araceae) Endemic to the Western Ghats. Cytologia 79: 359-363.

Hadlaczky, G. 2011. Mammalian Chromosome Engineering. Humana Press, New York City.

Haroun, S. A. and Alotaibi, M. K. 2015. Cytogenetic studies on two wild species of genus Echinochloa P. Beauv. from Saudi Arabia. Cytologia 80: 117-123.

Harrington, J. J., Van Bokkelen, G., Mays, R. W., Gustashaw, K. and Willard, H. F. 1997. Formation of de novo centromeres and construction of first-generation human artificial microchromosomes. Nat. Genet. 15: 345-355

Hirakawa, T. and Matsunaga, S. 2016. Chromatin tagging systems contribute to live imaging analyses for chromatin dynamics. Cytologia 81: 121-123.

Hizume, M. 2015. Fluorescent band pattern of chromosomes in Pseudolarix amabilis, Pinaceae. Cytologia 80: 151-157.

Hizume, M. and Kan, M. 2015. Fluorescent banding pattern of chromosomes in Araucaria araucana, Araucariaceae. Cytologia 80: 399-403.

Hoshiya, H., Kazuki, Y., Abe, S., Takiguchi, M., Kajitani, N., Watanabe, Y., Yoshino, T., Shirayoshi, Y., Higaki, K., Messina, G., Cossu, G. and Oshimura, M. 2009. A highly stable and nonintegrated human artificial chromosome (HAC) containing the 2.4 $\mathrm{Mb}$ entire human dystrophin gene. Mol. Ther. 17: 309-317.

Houben, A., Dawe, R. K., Jiang, J. and Schubert, I. 2008. Engineered plant minichromosomes: A bottom-up success? Plant Cell 20: 8-10.

Ikeno, M., Grimes, B., Okazaki, T., Nakano, M., Saitoh, K., Hoshino, H., McGill, N. I., Cooke, H. and Masumoto, H. 1998. Construction of YAC-based mammalian artificial chromosomes. Nat. Biotechnol. 16: 431-439.

Imran, M. K., Sultana, S. S. and Alam, S. S. 2015. Differential chromosome banding and RAPD analysis in three varieties of Glycine $\max$ (L.) Merr. Cytologia 80: 447-455.

Irvine, D. V., Shaw, M. L., Choo, K. H. and Saffery, R. 2005. Engineering chromosomes for delivery of therapeutic genes. Trends Biotechnol. 23: 575-583.

Itzhaki, J. E., Barnette, M. A., MacCarthy, A. B., Buckle, V. J., Brown, W. R. and Porter, A. C. 1992. Targeted breakage of a human chromosome mediated by cloned human telomeric DNA. Nat. Genet. 2: 283-287.

Jantarat, S., Khunsook, S., Supanuam, P., Jeewattana, S., Kaewsri, S. and Tanomtong, A. 2014a. The first chromosome analysis and localization of the nucleolar organizer region of Phayre's Flying Squirrel, Hylopetes phayrei (Rodentia, Sciuridae) in Thailand. Cytologia 79: 3-14.

Jantarat, S., Supanuam, P., Tanomtong, A., Khunsook, S., Prakrongrak, N. and Kaewsri, S. 2014b. Chromosome analysis and morphometric of Intermediate Roundleaf Bat, Hipposideros larvatus (Chiroptera, Hipposideridae) by conventional, GTG-banding and Ag-NOR banding techniques. Cytologia 79: 445-456.

Jumrusthanasan, S., Supiwong, W., Suvarnaraksha, A., Jiwyam, W., Pinthong, K. and Tanomtong, A. 2015. First karyological analysis of the Vermiculate Spinefoot, Siganus vermiculatus (Perciformes, Siganidae) from Thailand. Cytologia 80: 111-116.

Kabir, M. A. and Rustchenko, E. 2005. Determination of gaps by con- tig alignment with telomere-mediated chromosomal fragmentation in Candida albicans. Gene 345: 279-287.

Kaewmad, P., Monthatong, M., Supiwong, W., Saowakoon, S. and Tanomtong, A. 2014. Natural autotetraploid and chromosomal characteristics in the subfamily Botiinae (Cypriniformes, Cobitinae) from Northeast Thailand. Cytologia 79: 299-313.

Kaewsri, S., Saenjundaeng, P., Jumrusthanasan, S., Suksuwan, R., Tanomtong, A. and Supiwong, W. 2014a. The First Report of NORs and Chromosome analysis of Tripletail Wrasse, Cheilinus trilobatus (Perciformes: Labridae). Cytologia 79: 437-443.

Kaewsri, S., Tanomtong, A., Getlekha, N., Saenjundaeng, P., Suksuwan, R. and Supiwong, W. 2014b. Standardized karyotype and idiogram of Quoy's Parrotfish, Scarus quoyi (Perciformes: Scaridae) by conventional staining and Ag-NOR banding techniques. Cytologia 79: 429-435.

Kaewsri, S., Yodmuang, S., Tanomtong, A., Patawang, I., Jumrusthanasan, S. and Pinthong, K. 2014c. Cytogenetics of the skinks (Reptilia, Scincidae) from Thailand; I: Chromosome analyses of the Common Sun Skink (Eutropis multifasciata). Cytologia 79: 457-466.

Kantek, D. L. Z., Peres, W. A. M. and Moreira-filho, O. 2015. Cytogenetics of Trichomycterus brasiliensis (Siluriformes: Trichomycteridae) from the Upper São Francisco River Basin (MG). Cytologia 80: 25-29.

Kapusi, E., Ma, L., Teo, C. H., Hensel, G., Himmelbach, A., Schubert, I., Mette, M. F., Kumlehn, J. and Houben, A. 2012. Telomeremediated truncation of barley chromosomes. Chromosoma 121: 181-190.

Karpen, G. H. and Allshire, R. C. 1997. The case for epigenetic effects on centromere identity and function. Trends Genet. 13: 489-496.

Kasiroek, W., Luangoon, N., Getlekha, N., Saowakoon, S., Phinrub, W. and Tanomtong, A. 2014. First report on heteromorphic NORs and chromosome analysis of Rolland's Demoiselle, Chrysiptera rollandi (Perciformes, Pomacentrinae) by conventional and Ag-NOR staining techniques. Cytologia 79: 289-297.

Katoh, M., Ayabe, F., Norikane, S., Okada, T., Masumoto, H., Horike, S., Shirayoshi, Y. and Oshimura, M. 2004. Construction of a novel human artificial chromosome vector for gene delivery. Biochem. Biophys. Res. Commun. 321: 280-290.

Kaur, M. and Singhal, V. K. 2015. Cytomorphological diversity in some members of family Asteraceae from the ecologically disturbed habitats of Solang Valley, Kullu District, Himachal Pradesh. Cytologia 80: 203-222.

Kazuki, Y., Hoshiya, H., Kai, Y., Abe, S., Takiguchi, M., Osaki, M., Kawazoe, S., Katoh, M., Kanatsu-Shinohara, M., Inoue, K., Kajitani, N., Yoshino, T., Shirayoshi, Y., Ogura, A., Shinohara, T., Barrett, J. C. and Oshimura, M. 2008. Correction of a genetic defect in multipotent germline stem cells using a human artificial chromosome. Gene Ther. 15: 617-624.

Khakhong, S., Supiwong, W., Tanomtong, A., Sriuttha, M., Jearranaiprepame, P., Soemphol, W. and Jiwyam, W. 2014. A first chromosomal characterization of NORs in splendid snakehead fish, Channa lucius (Perciformes, Channidae). Cytologia 79: 133-139.

Kumar, A., Singh, B. K., Meena, H. S., Ram, B., Singh, V. V. and Singh, D. 2015. Cytogenetical investigations in colchicineinduced tetraploids of Brassica fruticulosa: An important wild relative of cultivated Brassicas. Cytologia 80: 223-230.

Kumar, R., Sahoo, P. K., Vishwanath, W. and Barat, A. 2014. Karyotype of a new loach Schistura obliquofascia and a mahseer Puntius chelynoides from Kumaun Hills of Himalaya. Cytologia 79: 243-246.

Kuroiwa, Y., Shinohara, T., Notsu, T., Tomizuka, K., Yoshida, H., Takeda, S., Oshimura, M. and Ishida, I. 1998. Efficient modification of a human chromosome by telomere-directed truncation in high homologous recombination-proficient chicken DT40 cells. 
Nucleic Acids Res. 26: 3447-3448.

Li, Y., Meng, Y. and Qian, Z. 2015. Karyological studies of 20 populations of Psammosilene tunicoides. Cytologia 80: 373-381.

Lombello, R. A. and Pinto-maglio, C. A. F. 2014. Cytogenetics and reproductive biology of Bixa orellana L. (Bixaceae). Cytologia 79: 379-386.

Mahbub, M., Sultana, S. S., Habib, M. A. and Alam, S. S. 2014. Karyotype and RAPD analysis of Allium tuberosum Rottl. ex Spreng. and three specimens of Allium cepa L. Cytologia 79: 409-418.

Maneechot, N., Supiwong, W., Jumrusthanasan, S., Siripiyasing, P., Pinthong, K. and Tanomtong, A. 2015. Chromosomal characteristics of the royal knifefish, Chitala blanci (Osteoglossiformes, Notopteridae) by conventional and Ag-NOR staining techniques. Cytologia 80: 159-166.

Manzum, A. A., Sultana, S. S., Warasy, A. A., Begum, R. and Alam, S. S. 2014. Characterization of four specimens of Allium sativum L. by differential karyotype and RAPD analysis. Cytologia 79: 419-426.

Martin, E., Çetin, Ö., Duran, A., Doğan, B. and Traş, Z. 2015. New karyotypes in some species of Asteraceae from Turkey. Cytologia 80: 237-248.

Matsunaga, S. 2016. FISH is in the limelight again beyond a cytogenetical technique for metaphase chromosomes. Cytologia 81: 3-6.

Mendiburo, M. J., Padeken, J., Fülöp, S., Schepers, A. and Heun, P. 2011. Drosophila CENH3 is sufficient for centromere formation. Science 334: 686-690.

Miura, N. and Iwatsubo, Y. 2014. Chromosome studies of Meehania montis-koyae and M. urticifolia in Japan. Cytologia 79: 371-377.

Murata, M., Shibata, F., Hironaka, A., Kashihara, K., Fujimoto, S., Yokota, E. and Nagaki, K. 2013. Generation of an artificial ring chromosome in Arabidopsis by Cre/LoxP mediated recombination. Plant J. 74: 363-371.

Murray, A. W. and Szostak, J. W. 1983. Construction of artificial chromosomes in yeast. Nature 305: 189-193.

Nakano, M., Cardinale, S., Noskov, V. N., Gassmann, R., Vagnarelli, P., Kandels-Lewis, S., Larionov, V., Earnshaw, W. C. and Masumoto, H. 2008. Inactivation of a human kinetochore by specific targeting of chromatin modifiers. Dev. Cell 14: 507-522.

Nelson, A. D., Lamb, J. C., Kobrossly, P. S. and Shippen, D. E. 2011. Parameters affecting telomere-mediated chromosomal truncation in Arabidopsis. Plant Cell 23: 2263-2272.

Niwa, O., Matsumoto, T., Chikashige, Y. and Yanagida, M. 1989. Characterization of Schizosaccharomyces pombe minichromosome deletion derivatives and a functional allocation of their centromere. EMBO J. 8: 3045-3052.

Niwa, O., Matsumoto, T. and Yanagida, M. 1986. Construction of a mini-chromosome by deletion and its mitotic and meiotic behaviour in fission yeast. Mol. Gen. Genet. 203: 397-405.

O'Connor, T. P. and Crystal, R. G. 2006. Genetic medicines: Treatment strategies for hereditary disorders. Nat. Rev. Genet. 7: 261-276.

Ohzeki, J., Bergmann, J. H., Kouprina, N., Noskov, V. N., Nakano, M., Kimura, H., Earnshaw, W. C., Larionov, V. and Masumoto, H. 2012. Breaking the HAC barrier: Histone H3K9 acetyl/methyl balance regulates CENP-A assembly. EMBO J. 31: 2391-2402.

Parai, P. and Mukherjee, A. 2014. Cytomorphological studies of Aloe variegata L. and Aloe zebrina Baker (Xanthorrhoeaceae) by an image analyzing system. Cytologia 79: 281-286.

Park, G. M. 2015. Karyological Studies of Sinotaia quadrata (Benson, 1842) (Gastropoda: Viviparidae) of Korea. Cytologia 80: 89-93.

Patawang, I., Tanomtong, A., Jumrusthanasan, S., Kakampuy, W., Neeratanaphan, L. and Pinthong, K. 2014a. Chromosomal characteristics of NORs and karyological analysis of Tokay Gecko, Gekko gecko (Gekkonidae, Squamata) from mitotic and meiotic cell division. Cytologia 79: 315-324.

Patawang, I., Tanomtong, A., Jumrusthanasan, S., Neeratanaphan, L., Pinthong, K. and Jangsuwan, N. 2015. Karyological analysis of the Indo-Chinese water dragon, Physignathus cocincinus (Squamata, Agamidae) from Thailand. Cytologia 80: 15-23.

Patawang, I., Tanomtong, A., Phimphan, S., Chuaynkern, Y., Chuaynkern, C., Phaengphairee, P., Khrueanet, W. and Nithikulworawong, N. 2014b. The identification of sex-chromosomes and karyological analysis of rice frog, Fejervarya limnocharis (Anura, Ranidae) from northeast Thailand. Cytologia 79: 141150 .

Phan, B. H., Jin, W., Topp, C. N., Zhong, C. X., Jiang, J., Dawe, R. K. and Parrott, W. A. 2007. Transformation of rice with long DNAsegments consisting of random genomic DNA or centromerespecific DNA. Transgenic Res. 16: 341-351.

Phimphan, S., Tanomtong, A., Supiwong, W., Nithikulworawong, N., Suvarnaraksha, A. and Kaewsri, S. 2015. Karyological analysis of the Barramundi, Lates calcarifer (Perciformes, Latidae). Cytologia 80: 167-172.

Pierozzi, N. I. and Baroni, R. M. 2014. Karyotype analysis using C- and NOR-banding in Ramie [Boehmeria nivea (L.) Gaud.]. Cytologia 79: 261-268.

Pinthong, K., Maneechot, N., Tanomtong, A., Supiwong, W., Chanaboon, T. and Jangsuwan, N. 2015. The first karyological analysis and chromosomal characteristics of NORs of the cloudy grouper, Epinephelus erythrurus (Perciformes, Epinephelinae) in Thailand. Cytologia 80: 279-286.

Pinthong, K., Supiwong, W., Tanomtong, A., Hongsachart, P., Phaengphairee, P. and Chantarangsee, M. 2014. A first karyological analysis of the sand goby, Oxyeleotris marmoratus (Teleostei, Eleotridae) in Thailand by Ag-NOR staining technique. Cytologia 79: 127-132.

Qumsiyeh, M. B., Amr, Z. S., Srour, K. T. A. and Al-Fawaghra, N. 2014. Karyotype for Nebo hierichonticus (Simon 1872) from the Palestinian Territories (Scorpiones: Scorpionidae). Cytologia 79: 277-280.

Reuter, G. and Spierer, P. 1992. Position effect variegation and chromatin proteins. BioEssays 14: 605-612.

Rezaei, M., Naghavi, M. R., Hoseinzadeh, A. H., Abbasi, A. and Jahangiri, B. 2014. Study of karyological characteristics in Papaver bracteatum and Papaver somniferum. Cytologia 79: 187-194.

Samanta, D., Lahiri, K., Mukhopadhyay, M. J. and Mukhopadhyay, S. 2015. Karyomorphological analysis of different varieties of Tabernaemontana coronaria. Cytologia 80: 67-73.

Sato, K., Yamazaki, T. and Iwatsubo, Y. 2015. Karyotype analysis of three alpine Taraxacum species (Asteraceae) in Japan. Cytologia 80: 489-493.

Shibata, F. and Hizume, M. 2015. Multi-color fluorescence in situ hybridization. Cytologia 80: 385-392.

Supanuam, P., Tanomtong, A., Khunsook, S., Khrueanet, W., Pinthong, K. and Wonkaonoi, W. 2015. The first report on standardized karyotype and idiogram of Indochinese Silvered Langur, Trachypithecus germaini germaini (Primates, Colobinae) in Thailand. Cytologia 80: 183-192.

Supiwong, W., Tanomtong, A., Pinthong, K., Kaewmad, P., Poungnak, P. and Jangsuwan, N. 2015. The first chromosomal characteristics of nucleolar organizer regions and karyological analysis of pink anemonefish, Amphiprion perideraion (Perciformes, Amphiprioninae). Cytologia 80: 271-278.

Tahami, S. K., Chamani, E., Zare, N., Asghari-Zakaria, R., Mohebodini, M. and Joyce, D. 2014. Karyological characteristics of Lilium ledebourii Boiss and Lilium longiflorum Thunb. Cytologia 79: 547-552.

Tanomtong, A., Chaiyaphan, P., Supanuam, P., Puramongkol, T., Maneechot, N. and Jangsuwan, N. 2015. The standard karyotype of the Asiatic jackal, Canis aureus (Carnivora, Canidae) from Thai- 
land. Cytologia 80: 3-13.

Tanomtong, A., Khunsook, S., Wonkaonoi, W., Supanuam, P., Srisamoot, N. and Jumrusthanasan, S. 2014a. The first karyological study and natural NOR polymorphism in Banded langur, Presbytis femoralis (Primate, Colobinae). Cytologia 79: 29-39.

Tanomtong, A., Supiwong, W., Jearranaiprepame, P., Khakhong, S., Kongpironchuen, C. and Getlekha, N. 2014b. A new natural autotetraploid and chromosomal characteristics of dwarf snakehead fish, Channa gachua (Perciformes, Channidae) in Thailand. Cytologia 79: 15-27.

Teo, C. H., Ma, L., Kapusi, E., Hensel, G., Kumlehn, J., Schubert, I., Houben, A. and Mette, M. F. 2011. Induction of telomeremediated chromosomal truncation and stability of truncated chromosomes in Arabidopsis thaliana. Plant J. 68: 28-39.

Tungkajiwangkoon, S., Inagaki, A., Shirakawa, J. and Hoshi, Y. 2015. RAPD profiling of three Japanese Drosera species. Cytologia 80: 393-398.

Venkatesh, K. H. and Munirajappa 2015. Comparative micro-morphological and karyomorphological studies in three mulberry varieties (Morus spp.). Cytologia 80: 31-35.
Venkatesh, K. H., Nijagunaiah, R. and Munirajappa 2014. Cytogenetical studies in some triploid mulberry varieties (Moraceae). Cytologia 79: 365-369.

Walia, G. K., Kaur, H. and Kaur, J. 2015. Karyomorphological variations in the chromosome complement of Orthetrum taeniolatum of family Libellulidae (Odonata: Anisoptera). Cytologia 80: 95-99.

Wuebbles, R. and Jones, P. L. 2007. Engineered telomeres in transgenic Xenopus laevis. Transgenic Res. 16: 377-384.

$\mathrm{Xu}, \mathrm{C}$., Cheng, Z. and $\mathrm{Yu}, \mathrm{W}$. 2012. Construction of rice minichromosomes by telomere-mediated chromosomal truncation. Plant J. 70: 1070-1079.

Yin, Z., Plader, W. and Malepszy, S. 2004. Transgene inheritance in plants. J. Appl. Genet. 45: 127-144.

Yu, W., Han, F., Gao, Z., Vega, J. M. and Birchler, J. A. 2007. Construction and behavior of engineered minichromosomes in maize. Proc. Natl. Acad. Sci. U.S.A. 104: 8924-8929.

Yu, W., Lamb, J. C., Han, F. and Birchler, J. A. 2006. Telomeremediated chromosomal truncation in maize. Proc. Natl. Acad. Sci. U.S.A. 103: 17331-17336. 